\title{
Two-year clinical outcome of all-comers treated with three highly dissimilar contemporary coronary drug-eluting stents in the randomised BIO-RESORT trial
}

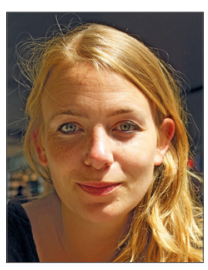

Marlies M. Kok ${ }^{1}$, MD; Paolo Zocca ${ }^{1}$, MD; Rosaly A. Buiten ${ }^{1}$, MD; Peter W. Danse ${ }^{2}$, MD, PhD; Carl E. Schotborgh 3 , MD; Martijn Scholte 4 , MD; Marc Hartmann¹, MD, PhD; Martin G. Stoel ${ }^{1}$, MD, PhD; K. Gert van Houwelingen ${ }^{1}, \mathrm{MD}$; Gerard C.M. Linssen ${ }^{5}$, MD, PhD; Carine J.M. Doggen ${ }^{6}, \mathrm{PhD}$; Clemens von Birgelen ${ }^{1,6 *}, \mathrm{MD}, \mathrm{PhD}$

1. Department of Cardiology, Thoraxcentrum Twente, Medisch Spectrum Twente, Enschede, the Netherlands; 2. Department of Cardiology, Rijnstate Hospital, Arnhem, the Netherlands; 3. Department of Cardiology, Haga Hospital, The Hague, the Netherlands; 4. Department of Cardiology, Albert Schweitzer Hospital, Dordrecht, the Netherlands; 5. Department of Cardiology, Hospital Group Twente, Almelo and Hengelo, the Netherlands; 6. Department of Health Technology and Services Research, MIRA - Institute of Technical Medicine and Biomedical Technology, University of Twente, Enschede, the Netherlands

M.M. Kok and P. Zocca contributed equally to this manuscript.

This paper also includes supplementary data published online at: http://www.pcronline.com/eurointervention/141st issue/163

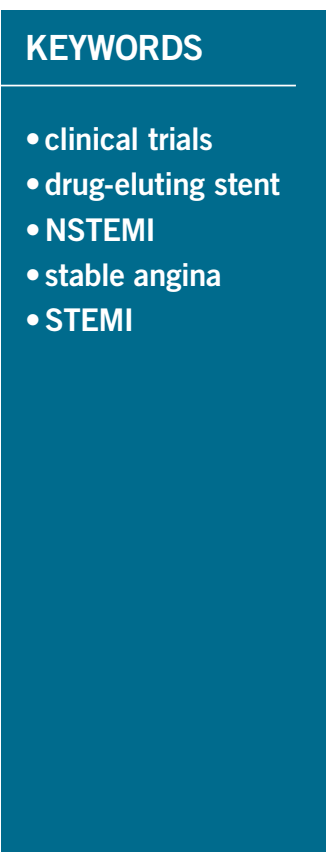

\section{Abstract}

Aims: The aim of the study was to evaluate the two-year clinical outcome of all-comer trial participants who were treated with two very different thin-strut biodegradable polymer versus thin-strut durable polymer drug-eluting stents (DES). Prolonged clinical outcome after discontinuation of dual antiplatelet therapy is of particular interest, given the highly dissimilar polymer types, amount, distribution, and degradation speed of both biodegradable polymer DES.

Methods and results: The BIO-RESORT trial (NCT01674803) randomly assigned 3,514 patients to treatment with biodegradable polymer SYNERGY everolimus-eluting stents (EES) or Orsiro sirolimuseluting stents (SES), or durable polymer Resolute Integrity zotarolimus-eluting stents (ZES). At two-year follow-up (available in 98.8\%), the rate of the primary composite endpoint target vessel failure (TVF) was $8.3 \%$ in ZES versus $6.8 \%$ in EES ( $p=0.19)$ and $6.6 \%$ in SES $(p=0.12)$. Landmark analyses at one year revealed differences between SES and ZES in the rates of target lesion revascularisation and target lesion failure ( $0.6 \%$ vs. $1.5 \%, \mathrm{p}=0.04$, and $1.1 \%$ vs. $2.4 \%, \mathrm{p}=0.02$, respectively) as well as other composite secondary endpoints that reached statistical significance.

Conclusions: At two-year follow-up, there was no significant between-DES difference in the rates of the primary endpoint. Landmark analyses provided a signal that the use of SES versus ZES might reduce the risk of repeat revascularisation after one-year follow-up.

*Corresponding author: Department of Cardiology, Thoraxcentrum Twente, Medisch Spectrum Twente, Postbus 50000, 


\section{Abbreviations}

DAPT dual antiplatelet therapy

EES everolimus-eluting stent

MACE major adverse cardiac events

MI myocardial infarction

PCI percutaneous coronary intervention

POCE patient-oriented composite endpoint

SES sirolimus-eluting stent

TLR target lesion revascularisation

TLF target lesion failure

TVF target vessel failure

ZES zotarolimus-eluting stent

\section{Introduction}

The lifelong presence of durable polymer-coated drug-eluting stents in coronary arteries has been associated with chronic inflammation, delayed arterial healing, and neoatherosclerosis, which may result in late adverse clinical events ${ }^{1}$. New-generation biodegradable polymer DES were designed to overcome these limitations by providing the antiproliferative benefits of durable polymer DES combined with the long-term safety of bare metal stents due to the absence of polymer residues ${ }^{2}$. The early-generation biodegradable polymer DES had thick struts and, in a large all-comers trial, showed similar efficacy and somewhat better long-term safety as compared to early-generation thick-strut durable polymer $\mathrm{DES}^{2,3}$. Novel biodegradable polymer DES have uncoated struts that are up to half as thick.

These very thin-strut biodegradable polymer DES have flexible designs and thin, refined coatings ${ }^{4}$ to accelerate re-endothelialisation and reduce the risk of ischaemic coronary events. The rapid resorption of the abluminal polymer in SYNERGYTM everolimus-eluting stents (EES) (Boston Scientific, Marlborough, MA, USA) results in a bare metal platform within four months, while the encompassing polymer coating of the Orsiro sirolimus-eluting stent (SES) (Biotronik, Bülach, Switzerland) is slowly degraded within approximately 18 months 5 . The one-year follow-up of the randomised BIORESORT trial demonstrated non-inferiority of both biodegradable

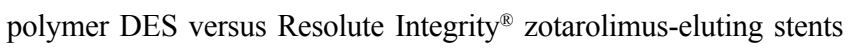
(ZES) (Medtronic, Santa Rosa, CA, USA) in 3,514 all-comer patients, but there was no short-term advantage ${ }^{6}$. Nevertheless, biodegradable polymer DES might still improve midterm or long-term outcomes.

Clinical outcome after discontinuation of dual antiplatelet therapy (DAPT) is of particular interest, given the highly dissimilar polymer types, amount, distribution, and degradation speed of the two biodegradable polymer DES tested. In the present study, DAPT was prescribed for 12 months in most patients and then stringently discontinued. Notably, BIO-RESORT is 1) the first randomised trial to assess both the biodegradable polymer SYNERGY and Orsiro stents, and 2) the first randomised trial to test SYNERGY EES in all-comers ${ }^{6}$. In the present study, we assessed the two-year clinical outcome of the BIO-RESORT allcomers who were treated with EES and SES versus ZES and followed a stringent DAPT discontinuation policy after one year.

\section{Methods STUDY DESIGN AND PATIENTS}

The investigator-initiated, multicentre randomised BIO-RESORT trial (TWENTE III) enrolled all-comers requiring percutaneous coronary intervention (PCI) with DES at four sites in the Netherlands (Thoraxcentrum Twente, Medisch Spectrum Twente, Enschede; Rijnstate Hospital, Arnhem; Haga Hospital, The Hague; Albert Schweitzer Hospital, Dordrecht $)^{5,6}$. In this three-arm clinical trial (ClinicalTrials.gov Identifier: NCT01674803), patients were randomly (1:1:1) assigned to either a platinum-chromium EES (SYNERGY), a cobalt-chromium SES (Orsiro), or a newgeneration thin-strut ZES (Resolute Integrity). All coronary syndromes, de novo and restenotic lesions, and coronary or bypass lesions were permitted. There was no limit for lesion length, reference vessel size, and number of lesions or vessels to be treated. The study design has been described previously ${ }^{5,6}$.

The trial complied with the CONSORT 2010 Statement and the Declaration of Helsinki and was approved by the Medical Ethics Committee Twente and the institutional review boards of all participating centres. All patients provided written informed consent.

\section{PROCEDURES AND FOLLOW-UP}

Treatment was performed according to current medical guidelines and the physician's judgement ${ }^{6}$. Lesion predilation, direct stenting and stent post-dilation were left to the operator's discretion. The SYNERGY stent elutes everolimus within three months from a $4 \mu \mathrm{m}$ biodegradable PLGA (poly[lactic-co-glycolic acid]) coating that is located only on the abluminal side of $74 \mu \mathrm{m} / 79 \mu \mathrm{m} / 81 \mu \mathrm{m}$ platinum-chromium struts (for stent sizes $\leq 2.5 \mathrm{~mm} / 3.0-3.5 \mathrm{~mm} / 4.0 \mathrm{~mm}$, respectively) and resorbed within four months $s^{5,7}$. The sirolimus-eluting Orsiro stent has $60 \mu \mathrm{m}$ or $80 \mu \mathrm{m}$ (for stents $\leq 3.0 \mathrm{~mm}$ or $>3.0 \mathrm{~mm}$ ) cobalt-chromium struts that are circumferentially covered by an asymmetrical hybrid coating that is thicker on the abluminal side $(7.4 / 3.5 \mu \mathrm{m})^{5}$. Its biodegradable PLLA (poly[L-lactide] acid) elutes the drug within three months, is fully resorbed within 18 months, and covers a thin passive coating of amorphous silicon carbide ${ }^{5}$. The zotarolimus-eluting Resolute Integrity stent has thin $91 \mu \mathrm{m}$ cobalt-chromium struts, covered by a $6 \mu \mathrm{m}$ zotarolimus-eluting blend of three durable polymers.

Clinical follow-up was obtained at visits to outpatient clinics or, if not feasible, by telephone follow-up or medical questionnaire. A clinical research organisation (Cardiovascular Research and Education, Enschede, the Netherlands) coordinated trial and data management.

Clinical endpoints were pre-specified, using definitions of the Academic Research Consortium ${ }^{5,8}$. The primary composite endpoint of target vessel failure (TVF) assessed device efficacy and patient safety and consisted of cardiac death, target vessel-related myocardial infarction (MI), or clinically indicated target vessel revascularisation. Secondary endpoints included: target lesion revascularisation (TLR), target lesion failure (TLF, a composite of cardiac death, any MI not clearly attributable to a non-target vessel, or clinically driven TLR), major adverse cardiac events 
(MACE, a composite of all-cause death, any MI, or emergent coronary bypass surgery, or repeat clinically indicated TLR), the most global patient-oriented composite endpoint (POCE, a composite of all-cause death, any MI, or any repeat coronary revascularisation), and definite-or-probable stent thrombosis.

Data monitoring, processing of clinical outcome data, and independent clinical event adjudication were performed by an independent clinical research organisation (Diagram, Zwolle, the Netherlands).

\section{STATISTICAL ANALYSIS}

Categorical variables were assessed with the chi-square or Fisher's exact test, as appropriate, while continuous variables were assessed with the Student's t-test. The time to primary endpoint and components thereof was assessed according to KaplanMeier methods; the log-rank test was applied for between-group comparisons. Hazard ratios were computed using Cox proportional hazards regression analysis. We performed landmark analyses of the primary endpoint and all secondary endpoints by using the one-year landmark. P-values $<0.05$ were considered significant. P-values and confidence intervals were two-sided. Statistical analyses were performed with SPSS, Version 22.0 (IBM Corp., Armonk, NY, USA).

\section{Results}

From December 2012 to August 2015, a total of 3,514 patients were randomised and assessed at four clinical sites in the Netherlands, of whom 3,472 (98.8\%) completed two-year follow-up or had died. Eleven $(0.3 \%)$ patients were lost to follow-up, and $31(0.9 \%)$ withdrew their consent (censored at the moment of dropout).

Table 1 presents the baseline characteristics of the trial participants, stratified for assigned treatment arms. Most patients presented with acute coronary syndromes $(69.7 \%)$ and $79.2 \%$ of patients had $\geq 1$ complex target lesion. At two years, DAPT rates were low (Table 2). Between stent arms, there were no statistically significant differences in the use of antiplatelet agents and oral anticoagulation therapy.

The two-year clinical outcome data are presented in Table 3. At two-year follow-up, the primary endpoint TVF occurred in $79 / 1,172(6.8 \%)$ patients assigned to EES, 76/1,169 (6.6\%) patients assigned to SES, and 96/1,173 (8.3\%) patients assigned to ZES. These differences were statistically non-significant for both EES and SES versus ZES ( $p=0.19$, and $p=0.12$, respectively). The event rates of TVF and its individual components are displayed in Figure 1. The event rates for the primary endpoint were consistent across subgroups, except for patients who were treated for bypass grafts (Supplementary Table 1A, Supplementary Table 1B). Definite stent thrombosis was an infrequent event that occurred in $7(0.6 \%), 5(0.4 \%)$ and $6(0.5 \%)$ patients, respectively. Definiteor-probable stent thrombosis rates were similar among treatment groups (11 [1.0\%], 7 [0.6\%], and 9 [0.8\%], respectively; $\mathrm{p}=0.65$ and $\mathrm{p}=0.62$ ) (Table 3, Figure 2).

In landmark analyses between one- and two-year follow-up, patients assigned to SES had, compared to patients assigned to ZES, significantly lower rates of TLR $(0.6 \%$ vs. $1.5 \%, p=0.04)$ and TLF ( $1.1 \%$ vs. $2.4 \%, \mathrm{p}=0.02)$ (Table 4, Figure 3 ). In addition, the rates of the composite endpoints MACE and POCE were significantly lower in SES versus ZES (0.8\% vs. $2.2 \%$ and $3.2 \%$ vs. $5.3 \%$, respectively, both $\mathrm{p}=0.01$ ), while the TVF rate was $1.9 \%$ versus $3.0 \%(\mathrm{p}=0.10)$. TLR as well as non-cardiovascular death contributed to the differences in MACE and POCE. A detailed description of the TLR cases is presented in Supplementary Table 2. Landmark analyses between one and two years for TVF and secondary endpoints showed no statistically significant differences for EES versus ZES (Table 4).

\section{Discussion}

The present analysis shows that, at two-year follow-up, the rate of the primary endpoint TVF is similar in both very thin-strut biodegradable polymer DES and the reference durable polymer DES. This supports the concept in PCI all-comers that the combination of very thin struts with biodegradable polymers is associated with safety and efficacy which, during the first two years from implantation, are similar to DES with durable polymer coatings.

Landmark analyses revealed lower rates of TLR and several secondary composite endpoints (TLF, MACE, and POCE) in SES versus ZES during the second year of follow-up. This signal of a potentially lower long-term risk of target lesion recurrence following treatment with SES is of interest but should be interpreted cautiously. During the second year of follow-up, the sirolimus has already been eluted for $>9$ months, while the process of polymer resorption is just finishing. Clinical data suggest that this very slow polymer degradation might be advantageous, potentially by minimising vascular inflammation. In addition, the very high rate of stent post-dilation in $>80 \%$ of patients could have resulted in a deeper embedding of the very thin stent struts, which might have contributed to the overall favourable event rates.

Potential benefits of the biodegradable polymer DES might be seen no earlier than after several years ${ }^{3,9,10}$. Clinical event rates after discontinuation of DAPT are of particular interest, given the highly dissimilar polymer types, amount, distribution, and degradation speed of SYNERGY and Orsiro tested in the BIO-RESORT trial. In our study, DAPT was prescribed for 12 months in most patients and then stringently discontinued, as is common practice in the Netherlands. At two-year follow-up, DAPT use was $8 \%$, while in another large-scale randomised DES trial that studied SYNERGY EES the DAPT rate was $47 \%$ (Kereiakes DJ et al. Late clinical outcomes after bioresorbable or permanent polymer everolimus-eluting stents: 2-year results from the EVOLVE II randomized trial. Presented at ACC 2017, Washington DC, USA, 17 March 2017).

\section{RANDOMISED DES STUDIES WITH SYNERGY AND ORSIRO}

BIO-RESORT is the first randomised study to examine both SYNERGY and Orsiro biodegradable polymer DES, and the first randomised trial to assess SYNERGY EES in all-comers. This and other randomised trials have demonstrated the short-term safety and efficacy of both novel biodegradable polymer DES, which were found to be similar to established new-generation durable polymer $\mathrm{DES}^{6,11}$. 
Table 1. Clinical characteristics of patients, lesions, and procedures.

\begin{tabular}{|c|c|c|c|c|}
\hline & $\begin{array}{c}\text { All patients } \\
N=3,514\end{array}$ & $\begin{array}{c}\text { EES } \\
N=1,172\end{array}$ & $\begin{array}{c}\text { ZES } \\
N=1,173\end{array}$ & $\begin{array}{c}\text { SES } \\
N=1,169\end{array}$ \\
\hline Age, yrs & $63.9 \pm 10.8$ & $64.0 \pm 10.7$ & $63.6 \pm 10.9$ & $64.2 \pm 10.7$ \\
\hline Male & $2,547(72.5)$ & $845(72.1)$ & $848(72.3)$ & $854(73.1)$ \\
\hline Body mass index $\left(\mathrm{kg} / \mathrm{m}^{2}\right)$ & $27.4 \pm 4.2$ & $27.6 \pm 4.2$ & $27.3 \pm 4.0$ & $27.4 \pm 4.2$ \\
\hline Current smoker & $1,031 / 3,422(30.1)$ & $336 / 1,135(29.6)$ & $354 / 1,143(31.0)$ & $341 / 1,144(29.8)$ \\
\hline Family history of coronary artery disease & $1,557 / 3,372(46.2)$ & $512 / 1,114(46.0)$ & $529 / 1,138(46.5)$ & $516 / 1,120(46.1)$ \\
\hline Diabetes mellitus, medically treated & $624(17.8)$ & $203(17.3)$ & 210 (17.9) & $211(18.0)$ \\
\hline Hypertension & $1,624(46.2)$ & $520(44.4)$ & $554(47.2)$ & $550(47.0)$ \\
\hline Hypercholesterolaemia & $1,335(38.0)$ & $422(36.0)$ & $450(38.4)$ & $463(39.6)$ \\
\hline Previous myocardial infarction & 649 (18.5) & $192(16.4)$ & $248(21.1)$ & 209 (17.9) \\
\hline Previous stroke & $231(6.6)$ & $74(6.3)$ & $81(6.9)$ & $76(6.5)$ \\
\hline Renal insufficiency ${ }^{\pi}$ & $108(3.1)$ & $29(2.5)$ & $33(2.8)$ & 46 (3.9) \\
\hline Previous percutaneous coronary intervention & $626(17.8)$ & $214(18.3)$ & 198 (16.9) & $214(18.3)$ \\
\hline Previous coronary artery bypass grafting & $267(7.6)$ & $91(7.8)$ & $96(8.2)$ & $80(6.8)$ \\
\hline \multicolumn{5}{|l|}{ Clinical presentation } \\
\hline Acute coronary syndrome & $2,449(69.7)$ & $816(69.6)$ & $815(69.5)$ & $818(70.0)$ \\
\hline Stable angina & $1,065(30.3)$ & $356(30.4)$ & $358(30.5)$ & $351(30.0)$ \\
\hline \multicolumn{5}{|l|}{ Lesion characteristics ${ }^{\ddagger}$} \\
\hline At least one complex lesion & $2,783(79.2)$ & $903(77.0)$ & $938(80.0)$ & $942(80.6)$ \\
\hline At least one bifurcation lesion & $1,236(35.2)$ & $415(35.4)$ & 409 (34.9) & $412(35.2)$ \\
\hline At least one chronic total occlusion & $139(4.0)$ & $44(3.8)$ & $48(4.1)$ & $47(4.0)$ \\
\hline At least one bypass graft lesion & $70(2.0)$ & $18(1.5)$ & $30(2.6)$ & $22(1.9)$ \\
\hline At least one ostial lesion & $252(7.2)$ & $97(8.3)$ & $81(6.9)$ & $74(6.3)$ \\
\hline At least one severely calcified lesion & $783(22.3)$ & $252(21.5)$ & $265(22.6)$ & $266(22.8)$ \\
\hline \multicolumn{5}{|l|}{ Procedural characteristics } \\
\hline Implantation of assigned stents only & $3,446(98.1)$ & $1,155(98.5)$ & $1,147(97.8)$ & $1,144(97.9)$ \\
\hline Total stent length per patient, $\mathrm{mm}$ & $31(20-50)$ & $32(20-48)$ & $30(22-52)$ & $30(18-49)$ \\
\hline Direct stenting & 589 (16.8) & 208 (17.7) & $174(14.8)$ & 207 (17.7) \\
\hline Post-dilation & $2,833(80.6)$ & $960(81.9)$ & 927 (79.0) & 946 (80.9) \\
\hline Multivessel treatment & $640(18.2)$ & $201(17.2)$ & $220(18.8)$ & $219(18.7)$ \\
\hline Radial approach & $1,597(45.4)$ & $523(44.6)$ & $544(46.4)$ & $530(45.3)$ \\
\hline Fractional flow reserve use & $440(12.5)$ & $147(12.5)$ & $155(13.2)$ & $138(11.8)$ \\
\hline
\end{tabular}

Table 2. Medication at 1- and 2-year follow-up.

\begin{tabular}{|c|c|c|c|c|c|}
\hline & All patients & EES & ZES & SES & $p$-value \\
\hline Medication at 1 year & $N=3,432$ & $N=1,142$ & $N=1,146$ & $\mathrm{~N}=1,144$ & \\
\hline Dual antiplatelet therapy & $2,939(85.6)$ & $976(85.5)$ & $989(86.3)$ & $974(85.1)$ & 0.72 \\
\hline with clopidogrel & $1,528(44.5)$ & $500(43.8)$ & $517(45.1)$ & $511(44.7)$ & 0.81 \\
\hline with ticagrelor or prasugrel & $1,411(41.1)$ & $476(41.7)$ & $472(41.2)$ & $463(40.5)$ & 0.84 \\
\hline OAC with $\mathrm{P} 2 \mathrm{Y}_{12}$ inhibitor & $355(10.3)$ & $123(10.8)$ & $112(9.8)$ & $120(10.5)$ & 0.72 \\
\hline Medication at 2 years & $N=3,399$ & $N=1,131$ & $\mathrm{~N}=1,132$ & $N=1,136$ & \\
\hline Dual antiplatelet therapy & 267 (7.9) & $87(7.7)$ & $103(9.1)$ & $77(6.8)$ & 0.12 \\
\hline with clopidogrel & $158(4.6)$ & $51(4.5)$ & $62(5.5)$ & $45(4.0)$ & 0.22 \\
\hline with ticagrelor or prasugrel & $109(3.2)$ & $36(3.2)$ & $41(3.6)$ & $32(2.8)$ & 0.55 \\
\hline OAC with P2Y $Y_{12}$ inhibitor & $45(1.3)$ & $20(1.8)$ & $14(1.2)$ & $11(1.0)$ & 0.24 \\
\hline
\end{tabular}


Table 3. Clinical events until 2-year follow-up.

\begin{tabular}{|c|c|c|c|c|c|c|c|}
\hline & \multicolumn{7}{|c|}{ All patients $\mathrm{N}=3,514$} \\
\hline & $\begin{array}{c}\text { EES } \\
N=1,172\end{array}$ & $\begin{array}{c}\text { ZES } \\
N=1,173\end{array}$ & $\begin{array}{c}\text { SES } \\
N=1,169\end{array}$ & $\begin{array}{c}\text { Hazard ratio } \\
(95 \% \text { CI) EES vs. ZES }\end{array}$ & $\begin{array}{l}p \text {-log- } \\
\text { rank }\end{array}$ & $\begin{array}{c}\text { Hazard ratio } \\
\text { (95\% CI) SES vS. ZES }\end{array}$ & $\begin{array}{l}p \text {-log- } \\
\text { rank }\end{array}$ \\
\hline Death, any & $35(3.0)$ & $38(3.3)$ & $30(2.6)$ & $0.92(0.58-1.46)$ & 0.73 & $0.79(0.49-1.28)$ & 0.33 \\
\hline Cardiac death & $17(1.5)$ & $17(1.5)$ & $15(1.3)$ & $1.00(0.51-1.96)$ & 1.00 & $0.88(0.44-1.77)$ & 0.73 \\
\hline Myocardial infarction, any & $34(2.9)$ & $42(3.6)$ & $36(3.1)$ & $0.81(0.51-1.27)$ & 0.35 & $0.86(0.55-1.34)$ & 0.50 \\
\hline Target vessel myocardial infarction & $30(2.6)$ & $38(3.3)$ & $30(2.6)$ & $0.79(0.49-1.27)$ & 0.33 & $0.79(0.49-1.28)$ & 0.33 \\
\hline Coronary revascularisation, any & $71(6.1)$ & $94(8.1)$ & $75(6.4)$ & $0.75(0.55-1.02)$ & 0.07 & $0.80(0.59-1.08)$ & 0.14 \\
\hline Target vessel revascularisation & $39(3.4)$ & $56(4.8)$ & $43(3.7)$ & $0.70(0.46-1.05)$ & 0.08 & $0.77(0.51-1.40)$ & 0.19 \\
\hline Target lesion revascularisation & $27(2.4)$ & $34(3.0)$ & $25(2.2)$ & $0.80(0.48-1.32)$ & 0.37 & $0.74(0.44-1.23)$ & 0.24 \\
\hline Non-target vessel revascularisation & $36(3.1)$ & $39(3.4)$ & $34(3.0)$ & $0.92(0.59-1.45)$ & 0.73 & $0.88(0.55-1.39)$ & 0.57 \\
\hline Target vessel failure* & $79(6.8)$ & $96(8.3)$ & $76(6.6)$ & $0.82(0.61-1.10)$ & 0.19 & $0.79(0.58-1.07)$ & 0.12 \\
\hline Target lesion failure & $67(5.8)$ & $79(6.8)$ & $59(5.1)$ & $0.85(0.61-1.17)$ & 0.31 & $0.75(0.53-1.04)$ & 0.09 \\
\hline Major adverse cardiac events & $76(6.5)$ & $85(7.3)$ & $68(5.8)$ & $0.89(0.66-1.22)$ & 0.47 & $0.80(0.58-1.10)$ & 0.17 \\
\hline Patient-oriented composite endpoint & $125(10.6)$ & $147(12.5)$ & $121(10.3)$ & $0.85(0.67-1.07)$ & 0.17 & $0.82(0.65-1.05)$ & 0.11 \\
\hline Definite-or-probable stent thrombosis & $11(1.0)$ & $9(0.8)$ & $7(0.6)$ & $1.23(0.51-2.96)$ & 0.65 & $0.78(0.29-2.10)$ & 0.62 \\
\hline Definite stent thrombosis & $7(0.6)$ & $6(0.5)$ & $5(0.4)$ & $1.17(0.39-3.48)$ & 0.78 & $0.84(0.26-2.74)$ & 0.77 \\
\hline Probable stent thrombosis & $4(0.3)$ & $3(0.3)$ & $2(0.2)$ & $1.34(0.30-5.97)$ & 0.70 & $0.67(0.11-4.00)$ & 0.66 \\
\hline
\end{tabular}

The large-scale EVOLVE II trial examined 1,684 patients with up to moderate clinical risk, treated with SYNERGY EES versus durable polymer platinum-chromium EES, and demonstrated non-inferiority of SYNERGY at one-year follow-up ${ }^{7}$. The twoyear outcome showed similar safety and efficacy outcomes for both devices. Theoretically, the rapid polymer resorption in the SYNERGY may justify an abbreviated DAPT regime, which may be most advantageous in patients with an increased bleeding risk. In the randomised SYNERGY II Senior trial, elderly patients, treated with one or six months of DAPT after PCI, showed superior outcomes after PCI with SYNERGY EES versus bare metal stents ${ }^{12}$.

The biodegradable polymer Orsiro stent was previously tested against other DES in large randomised studies, which ascertained the safety and efficacy of Orsiro in greatly unrestricted patient populations $^{13-15}$. The SORT OUT VII trial studied 2,525 PCI patients, randomly assigned to the sirolimus-eluting Orsiro versus thick-strut biolimus-eluting biodegradable polymer DES and showed similar two-year clinical outcomes ${ }^{16}$. In addition, the two-year clinical

Table 4. Outcome difference between 1 and 2 years.

\begin{tabular}{|c|c|c|c|c|c|c|c|}
\hline & EES & ZES & SES & $\begin{array}{c}\text { Difference }(95 \% \text { CI) } \\
\text { EES vS. ZES }\end{array}$ & $\begin{array}{l}p-\log - \\
\text { rank }\end{array}$ & $\begin{array}{c}\text { Difference }(95 \% \text { CI) } \\
\text { SES vS. ZES }\end{array}$ & $\begin{array}{l}p-\log - \\
\text { rank }\end{array}$ \\
\hline Death, any & $15(1.3)$ & $19(1.7)$ & $11(1.0)$ & $-0.3(-1.3-0.6)$ & 0.50 & $-0.7(-1.6-0.2)$ & 0.14 \\
\hline Cardiac death & $7(0.6)$ & $7(0.6)$ & $5(0.4)$ & $0.0(-0.6-0.6)$ & $>0.99$ & $-0.2(-0.8-0.4)$ & 0.57 \\
\hline Myocardial infarction, any & $9(0.8)$ & $11(1.0)$ & $7(0.6)$ & $-0.2(-1.0-0.6)$ & 0.65 & $-0.4(-1.1-0.4)$ & 0.35 \\
\hline Target vessel myocardial infarction & $5(0.4)$ & $7(0.6)$ & $4(0.4)$ & $-0.2(-0.8-0.4)$ & 0.56 & $-0.3(-0.8-0.3)$ & 0.36 \\
\hline Coronary revascularisation, any & $31(2.8)$ & $42(3.8)$ & $26(2.4)$ & $-1.0(-2.5-0.4)$ & 0.18 & $-1.5(-2.9-0.0)$ & 0.049 \\
\hline Target vessel revascularisation & $16(1.4)$ & $26(2.3)$ & $17(1.5)$ & $-0.9(-2.0-0.2)$ & 0.12 & $-0.8(-1.9-0.3)$ & 0.17 \\
\hline Target lesion revascularisation & $10(0.9)$ & $17(1.5)$ & $7(0.6)$ & $-0.6(-1.5-0.3)$ & 0.18 & $-0.9(-1.7-0.0)$ & 0.04 \\
\hline Non-target vessel revascularisation & $19(1.7)$ & $18(1.6)$ & $10(0.9)$ & $0.1(-1.0-1.1)$ & 0.87 & $-0.7(-1.6-0.2)$ & 0.13 \\
\hline Target vessel failure & $24(2.2)$ & $33(3.0)$ & $21(1.9)$ & $-0.8(-2.2-0.5)$ & 0.22 & $-1.1(-2.4-0.2)$ & 0.10 \\
\hline Target lesion failure & $18(1.6)$ & $26(2.4)$ & $12(1.1)$ & $-0.7(-1.9-0.4)$ & 0.22 & $-1.3(-2.4--0.2)$ & 0.02 \\
\hline Major adverse cardiac events & $17(1.5)$ & $24(2.2)$ & $9(0.8)$ & $-0.6(-1.8-0.5)$ & 0.27 & $-1.4(-2.4--0.3)$ & 0.01 \\
\hline Patient-oriented composite endpoint & $44(4.1)$ & $57(5.3)$ & $34(3.2)$ & $-1.2(-3.0-0.6)$ & 0.18 & $-2.1(-3.8--0.4)$ & 0.01 \\
\hline Definite-or-probable stent thrombosis & $6(0.5)$ & $3(0.3)$ & $2(0.2)$ & $0.3(-0.3-0.8)$ & 0.31 & $-0.1(-0.5-0.3)$ & 0.66 \\
\hline Definite stent thrombosis & $3(0.3)$ & $3(0.3)$ & $1(0.1)$ & $0.0(-0.4-0.4)$ & $>0.99$ & $-0.2(-0.5-0.2)$ & 0.32 \\
\hline Probable stent thrombosis & $3(0.3)$ & $0(0.0)$ & $1(0.1)$ & $0.3(0.0-0.6)$ & 0.08 & $0.1(-0.1-0.3)$ & 0.32 \\
\hline
\end{tabular}



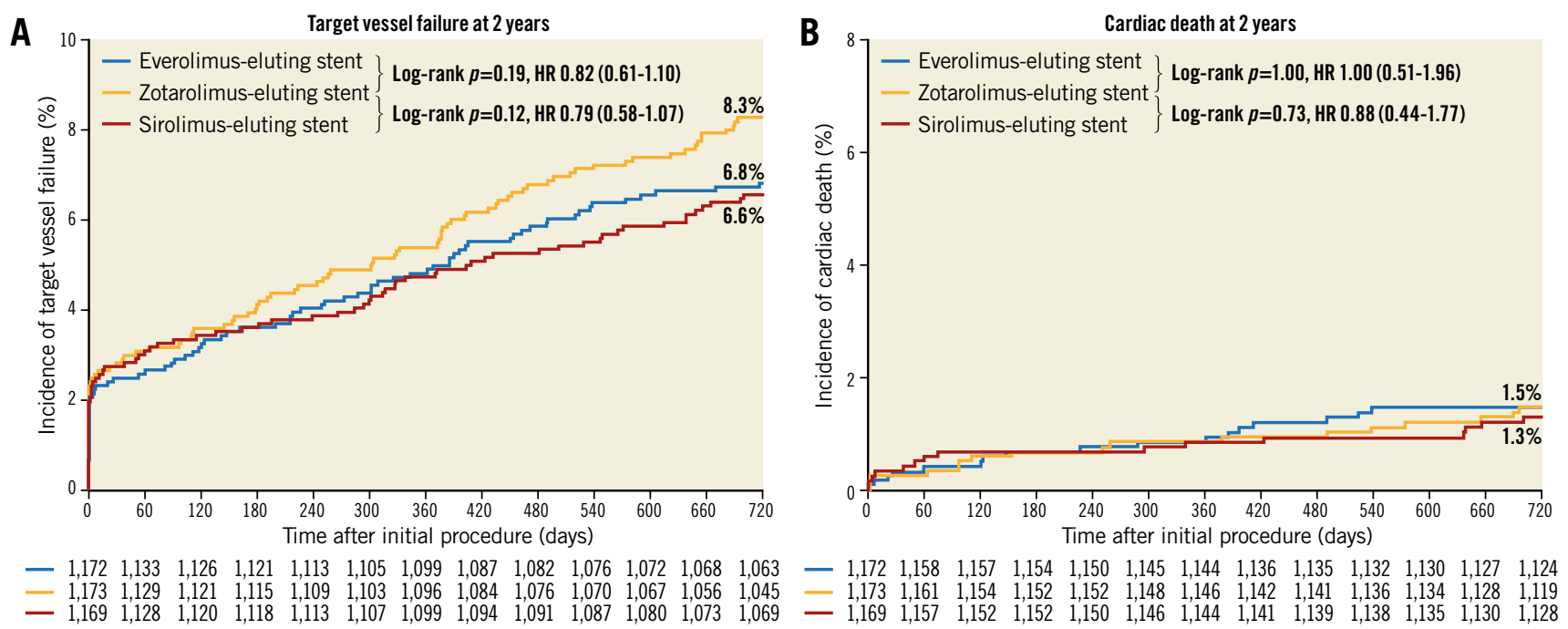

C

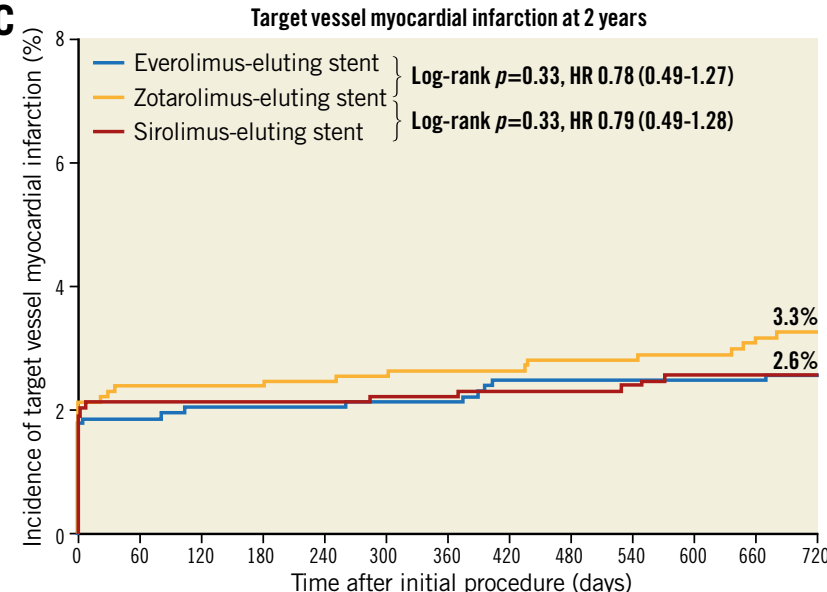

$\begin{array}{lllllllllllll}-1,172 & 1,137 & 1,134 & 1,131 & 1,127 & 1,121 & 1,120 & 1,110 & 1,109 & 1,106 & 1,104 & 1,101 & 1,097\end{array}$

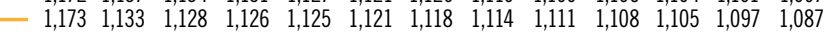

$\begin{array}{lllllllllllllll}- & 1,169 & 1,133 & 1,128 & 1,128 & 1,126 & 1,122 & 1,120 & 1,116 & 1,114 & 1,112 & 1,107 & 1,102 & 1,100\end{array}$

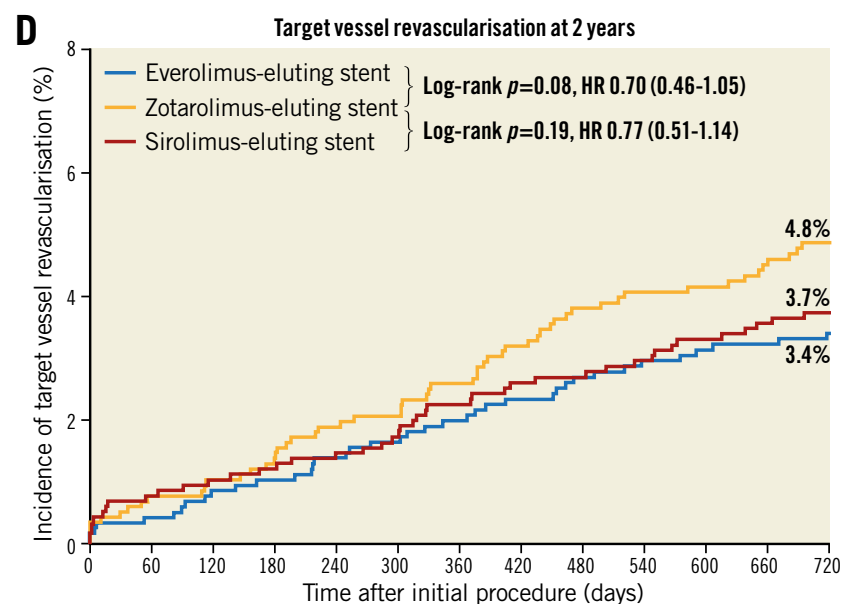

$\begin{array}{lllllllllllll}-1,172 & 1,153 & 1,147 & 1,142 & 1,134 & 1,126 & 1,121 & 1,110 & 1,105 & 1,099 & 1,095 & 1,092 & 1,087\end{array}$ $\begin{array}{lllllllllllll}1,173 & 1,153 & 1,145 & 1,139 & 1,133 & 1,127 & 1,120 & 1,109 & 1,101 & 1,093 & 1,090 & 1,080 & 1,068\end{array}$ $\begin{array}{lllllllllllllllll}- & 1,169 & 1,149 & 1,141 & 1,139 & 1,134 & 1,128 & 1,120 & 1,115 & 1,112 & 1,108 & 1,101 & 1,095 & 1,091\end{array}$

Figure 1. Kaplan-Meier cumulative event curves for the primary endpoint target vessel failure and its individual components at two-year follow-up. The primary endpoint target vessel failure (A), a composite of cardiac death (B), target vessel-related myocardial infarction (C), or clinically indicated target vessel revascularisation (D).

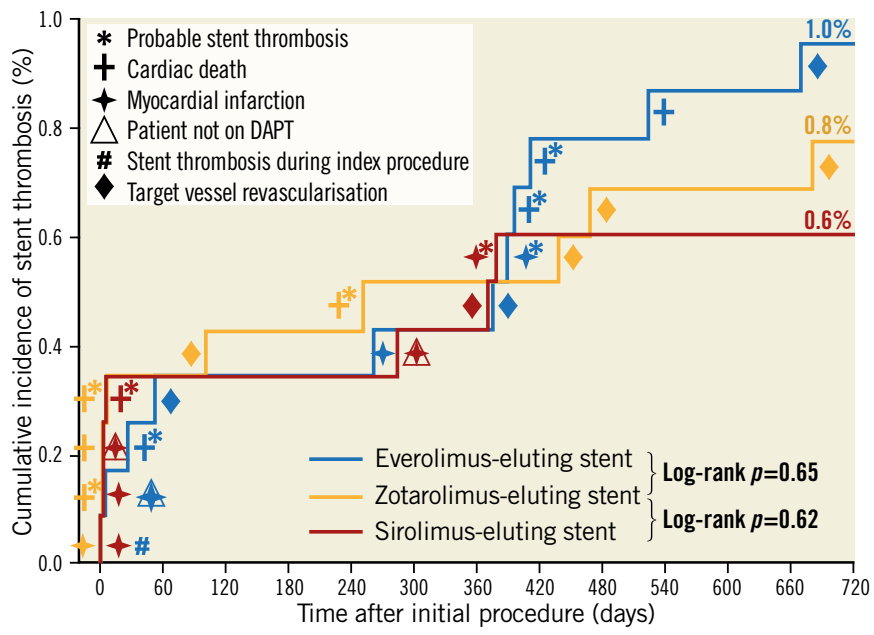

Figure 2. Incidence of definite or probable stent thrombosis at two-year follow-up. Symbols indicate the adverse events associated with stent thrombosis. 

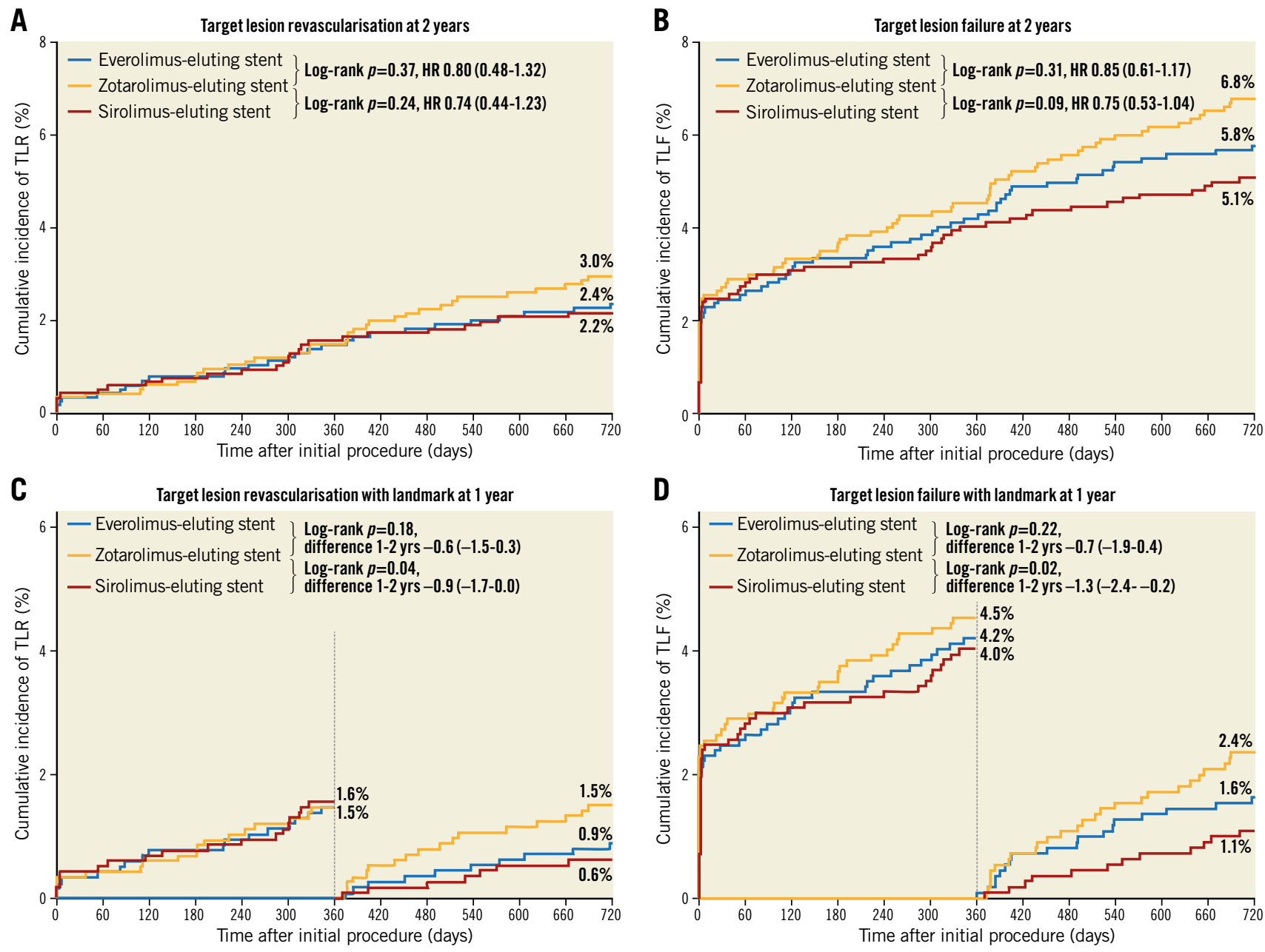

Figure 3. Kaplan-Meier cumulative event curves and landmark analyses for target lesion revascularisation and target lesion failure. Target lesion failure is a composite of cardiac death, target lesion-related myocardial infarction, or clinically driven target lesion revascularisation.

outcome of the randomised BIOSCIENCE trial in 2,119 patients was similar for patients treated with Orsiro versus durable polymer XIENCE $\mathrm{EES}^{17}$. In the BIOFLOW $\mathrm{V}$ randomised trial, Orsiro outperformed the durable polymer EES in a complex patient population, mainly based on a lower incidence of in-hospital MI, which did not translate into a difference in mortality ${ }^{18}$.

\section{BIODEGRADABLE POLYMER DES}

The struts of the novel biodegradable polymer stents are substantially thinner than those of the early biodegradable polymer stents $^{2}$. These very thin struts may have the advantage of reducing the incidence of side branch occlusion and periprocedural MI. A recent meta-analysis confirmed low MI rates after PCI with these devices but observed no benefit in clinically driven TLR versus other contemporary $\mathrm{DES}^{15}$. The reduction in strut thickness needs to be balanced against a decrease in radial strength, which can be achieved by modifications in stent design or the use of metal alloys with a higher strength. In addition, a potential disadvantage of the thin stent struts is their inferior radiographic visibility that is more marked in cobalt-chromium devices than in platinum-chromium stents ${ }^{19}$; theoretically, a lower visibility increases the risk of geometrical miss and related adverse cardiovascular events. Our current analysis, obtained in a broad population of PCI all-comers, shows no signal of increased adverse event risk for both very-thin strut biodegradable polymer DES but excellent outcomes until two-year follow-up.

The type and pharmacokinetic release profile of the antiproliferative drug as well as the reproducibility of drug elution varies across different biodegradable polymer $\mathrm{DES}^{3,20-22}$. Variance in polymer formulation and properties, such as polymer chain length and hydrophobicity, determines the course and products of polymer degradation ${ }^{18}$. All of the above may have an effect on the biological response of the coronary vessel, the speed of endothelialisation, the required minimum DAPT duration, and finally clinical outcome. Therefore, the various types of biodegradable polymer DES should not be considered a homogeneous class of devices. As a matter of fact, it is of the utmost importance to assess all individual biodegradable polymer DES carefully with a longer-term 
follow-up and to report clinical findings of the specific devices with their highly unique features in stent design, metal backbone, polymer type, composition of polymer and drug, and profiles of drug elution and polymer resorption.

\section{Limitations}

The findings of the landmark analyses should be considered hypothesis-generating. In addition, this study is not powered for reliable assessment of secondary clinical endpoints and, in particular, adverse events with a low incidence such as stent thrombosis. Despite high follow-up rates, systematic assessment of biomarkers, electrocardiographs and independent monitoring, the clinical event rates of the present study were low ${ }^{6}$.

\section{Conclusions}

Two years after stenting, the biodegradable polymer EES and SES showed favourable clinical outcomes that were comparable to the reference durable polymer ZES in a broad all-comers population, including many patients with acute coronary syndromes. Longterm follow-up will be of interest, as landmark analyses provided a signal that the use of SES might reduce the risk of repeat revascularisation after the first year of follow-up.

\section{Impact on daily practice}

Novel DES with very thin-strut biodegradable polymers may have advantages over stents with thin-strut durable polymers. The current two-year outcome data of the randomised BIORESORT trial show no statistically significant difference in adverse event rates between each of two novel very thin-strut biodegradable polymer DES and a thin-strut durable polymer reference DES. However, we found a signal that the biodegradable polymer sirolimus-eluting stent might be associated with a lower repeat revascularisation risk beyond one-year followup. Further long-term follow-up assessment is warranted and certainly of interest.

\section{Funding}

Biotronik, Boston Scientific, Medtronic.

\section{Conflict of interest statement}

C. von Birgelen indicates that the research department of Thoraxcentrum Twente has received institutional research grants from Biotronik, Boston Scientific, and Medtronic. The other authors have no conflicts of interest to declare.

\section{References}

1. Joner M, Finn AV, Farb A, Mont EK, Kolodgie FD, Ladich E, Kutys R, Skorija K, Gold HK, Virmani R. Pathology of drug-eluting stents in humans: delayed healing and late thrombotic risk. $J \mathrm{Am}$ Coll Cardiol. 2006;48:193-202.

2. Byrne RA, Stone GW, Ormiston J, Kastrati A. Coronary balloon angioplasty, stents, and scaffolds. Lancet. 2017;390:781-92.
3. Serruys PW, Farooq V, Kalesan B, de Vries T, Buszman P, Linke A, Klaus V, Eberli F, Wijns W, Morice MC, Di Mario C, Corti R, Antoni D, Sohn HY, Eerdmans P, Rademaker-Havinga T, van Es GA, Meier B, Jüni P, Windecker S. Improved safety and reduction in stent thrombosis associated with biodegradable polymer-based biolimus-eluting stents versus durable polymer-based sirolimus-eluting stents in patients with coronary artery disease: final 5-year report of the LEADERS (Limus Eluted From A Durable Versus ERodable Stent Coating) randomized, noninferiority trial. JACC Cardiovasc Interv. 2013;6:777-89.

4. Stefanini GG, Taniwaki M, Windecker S. Coronary stents: novel developments. Heart. 2014;100:1051-61.

5. Lam MK, Sen H, Tandjung K, van Houwelingen KG, de Vries AG, Danse PW, Schotborgh CE, Scholte M, Löwik MM, Linssen GC, IJzerman MJ, van der Palen J, Doggen CJ, von Birgelen C. Comparison of 3 biodegradable polymer and durable polymer-based drug-eluting stents in all-comers (BIO-RESORT): rationale and study design of the randomized TWENTE III multicenter trial. Am Heart J. 2014; 167:445-51.

6. von Birgelen C, Kok MM, van der Heijden LC, Danse PW, Schotborgh CE, Scholte M, Gin RMTJ, Somi S, van Houwelingen KG, Stoel MG, de Man FHAF, Louwerenburg JHW, Hartmann M, Zocca P, Linssen GCM, van der Palen J, Doggen CJM, Löwik MM. Very thin strut biodegradable polymer everolimuseluting and sirolimus-eluting stents versus durable polymer zotarolimus-eluting stents in allcomers with coronary artery disease (BIO-RESORT): a three-arm, randomised, non-inferiority trial. Lancet. 2016;388:2607-17.

7. Kereiakes DJ, Meredith IT, Windecker S, Lee Jobe R, Mehta SR, Sarembock IJ, Feldman RL, Stein B, Dubois C, Grady T, Saito S, Kimura T, Christen T, Allocco DJ, Dawkins KD. Efficacy and safety of a novel bioabsorbable polymer-coated, everolimuseluting coronary stent: the EVOLVE II randomized trial. Circ Cardiovasc Interv. 2015;8:e02372.

8. Vranckx P, Cutlip DE, Mehran R, Kint PP, Silber S, Windecker S, Serruys PW. Myocardial infarction adjudication in contemporary all-comer stent trials: balancing sensitivity and specificity. Addendum to the historical MI definitions used in stent studies. EuroIntervention. 2010;5:871-4.

9. Byrne RA, Kastrati A, Massberg S, Wieczorek A, Laugwitz KL, Hadamitzky M, Schulz S, Pache J, Fusaro M, Hausleiter J, Schömig A, Mehilli J; ISAR-TEST 4 Investigators. Biodegradable polymer versus permanent polymer drug-eluting stents and everolimus- versus sirolimus-eluting stents in patients with coronary artery disease: 3-year outcomes from a randomized clinical trial. J Am Coll Cardiol. 2011;58:1325-31.

10. Christiansen EH, Jensen LO, Thayssen P, Tilsted HH, Krusell LR, Hansen KN, Kaltoft A, Maeng M, Kristensen SD, Botker HE, Terkelsen CJ, Villadsen AB, Ravkilde J, Aaroe J, Madsen M, Thuesen L, Lassen JF; Scandinavian Organization for Randomized Trials with Clinical Outcome (SORT OUT) V investigators. Biolimus-eluting biodegradable polymer-coated stent versus durable polymer-coated sirolimus-eluting stent in unselected patients 
receiving percutaneous coronary intervention (SORT OUT V): a randomised non-inferiority trial. Lancet. 2013;381:661-9.

11. El-Hayek G, Bangalore S, Casso Dominquez A, Devireddy C, Jaber W, Kumar G, Mavromatis K, Tamis-Holland J, Samady H. Meta-Analysis of Randomized Clinical Trials Comparing Biodegradable Polymer Drug-Eluting Stent to Second-Generation Durable Polymer Drug-Eluting Stents. JACC Cardiovasc Interv. 2017;10:462-73.

12. Varenne O, Cook S, Sideris G, Kedev S, Cuisset T, Carrié D, Hovasse T, Garot P, El Mahmoud R, Spaulding C, Helft G, Diaz Fernandez JF, Brugaletta S, Pinar-Bermudez E, Mauri Ferre J, Commeau P, Teiger E, Bogaerts K, Sabate M, Morice MC, Sinnaeve PR; SENIOR investigators. Drug-eluting stents in elderly patients with coronary artery disease (SENIOR): a randomised single-blind trial. Lancet. 2018;391:41-50.

13. Pilgrim T, Heg D, Roffi M, Tüller D, Muller O, Vuilliomenet A, Cook S, Weilenmann D, Kaiser C, Jamshidi P, Fahrni T, Moschovitis A, Noble S, Eberli FR, Wenaweser P, Jüni P, Windecker S. Ultrathin strut biodegradable polymer sirolimus-eluting stent versus durable polymer everolimus-eluting stent for percutaneous coronary revascularisation (BIOSCIENCE): a randomised, single-blind, noninferiority trial. Lancet. 2014;384:2111-22.

14. Jensen LO, Thayssen P, Maeng M, Ravkilde J, Krusell LR, Raungaard B, Junker A, Terkelsen CJ, Veien KT, Villadsen AB, Kaltoft A, Tilsted HH, Hansen KN, Aaroe J, Kristensen SD, Hansen HS, Jensen SE, Madsen M, Botker HE, Berencsi K, Lassen JF, Christiansen EH. Randomized Comparison of a Biodegradable Polymer Ultrathin Strut Sirolimus-Eluting Stent With a Biodegradable Polymer Biolimus-Eluting Stent in Patients Treated With Percutaneous Coronary Intervention: The SORT OUT VII Trial. Circ Cardiovasc Interv. 2016 Jul;9(7).

15. Lipinski MJ, Forrestal BJ, Iantorno M, Torguson R, Waksman R. A comparison of the ultrathin Orsiro Hybrid sirolimus-eluting stent with contemporary drug-eluting stents: A meta-analysis of randomized controlled trials. Cardiovasc Revasc Med. 2018;19:5-11.

16. Jensen LO, Maeng M, Raungaard B, Hansen KN, Kahlert J, Jensen SE, Hansen HS, Lassen JF, Botker HE, Christiansen EH. Two-year outcome after biodegradable polymer sirolimus- and biolimus-eluting coronary stents (from the randomized SORT OUT VII trial). EuroIntervention. 2018;13:1587-90.

17. Zbinden R, Piccolo R, Heg D, Roffi M, Kurz DJ, Muller O, Vuilliomenet A, Cook S, Weilenmann D, Kaiser C, Jamshidi P, Franzone A, Eberli F, Jüni P, Windecker S, Pilgrim T. Ultrathin Strut Biodegradable Polymer Sirolimus-Eluting Stent Versus Durable-Polymer Everolimus-Eluting Stent for Percutaneous Coronary
Revascularization: 2-Year Results of the BIOSCIENCE Trial. J Am Heart Assoc. 2016;5:e003255.

18. Kandzari DE, Mauri L, Koolen JJ, Massaro JM, Doros G, Garcia-Garcia HM, Bennett J, Roguin A, Gharib EG, Cutlip DE, Waksman R; BIOFLOW V Investigators. Ultrathin, bioresorbable polymer sirolimus-eluting stents versus thin, durable polymer everolimus eluting stents in patients undergoing coronary revascularisation (BIOFLOW V): a randomised trial. Lancet. 2017;390: 1843-52.

19. Meredith IT, Verheye S, Dubois CL, Dens J, Fajadet J, Carrié D, Walsh S, Oldroyd KG, Varenne O, El-Jack S, Moreno R, Joshi AA, Allocco DJ, Dawkins KD. Primary endpoint results of the EVOLVE trial: a randomized evaluation of a novel bioabsorbable polymer-coated, everolimus-eluting coronary stent. J Am Coll Cardiol. 2012;59:1362-70.

20. Byrne RA, Kastrati A, Massberg S, Wieczorek A, Laugwitz KL, Hadamitzky M, Schulz S, Pache J, Fusaro M, Hausleiter J, Schömig A, Mehilli J; ISAR-TEST 4 Investigators. Biodegradable polymer versus permanent polymer drug-eluting stents and everolimus- versus sirolimus-eluting stents in patients with coronary artery disease: 3 -year outcomes from a randomized clinical trial. J Am Coll Cardiol. 2011;58:1325-31.

21. Basalus MW, Joner M, von Birgelen C, Byrne RA. Polymer coatings on drug-eluting stents: Samson's hair and Achilles' heel? EuroIntervention. 2013;9:302-5.

22. Navarese EP, Tandjung $\mathrm{K}$, Claessen B, Andreotti F, Kowalewski M, Kandzari DE, Kereiakes DJ, Waksman R, Mauri L, Meredith IT, Finn AV, Kim HS, Kubica J, Suryapranata H, Aprami TM, Di Pasquale G, von Birgelen C, Kedhi E. Safety and efficacy outcomes of first and second generation durable polymer drug eluting stents and biodegradable polymer biolimus eluting stents in clinical practice: comprehensive network meta-analysis. BMJ. 2013;347:f6530.

\section{Supplementary data}

Supplementary Table 1A. Subgroup analyses for the 2-year rates of target vessel failure: EES versus ZES.

Supplementary Table 1B. Subgroup analyses for the 2-year rates of target vessel failure: SES versus ZES.

Supplementary Table 2. Circumstances and consequences of TLR between 1 and 2 years.

The supplementary data are published online at:

http://www.pcronline.com/

eurointervention/141st_issue/163 


\section{Supplementary data}

Supplementary Table 1A. Subgroup analyses for the 2-year rates of target vessel failure: EES versus ZES.

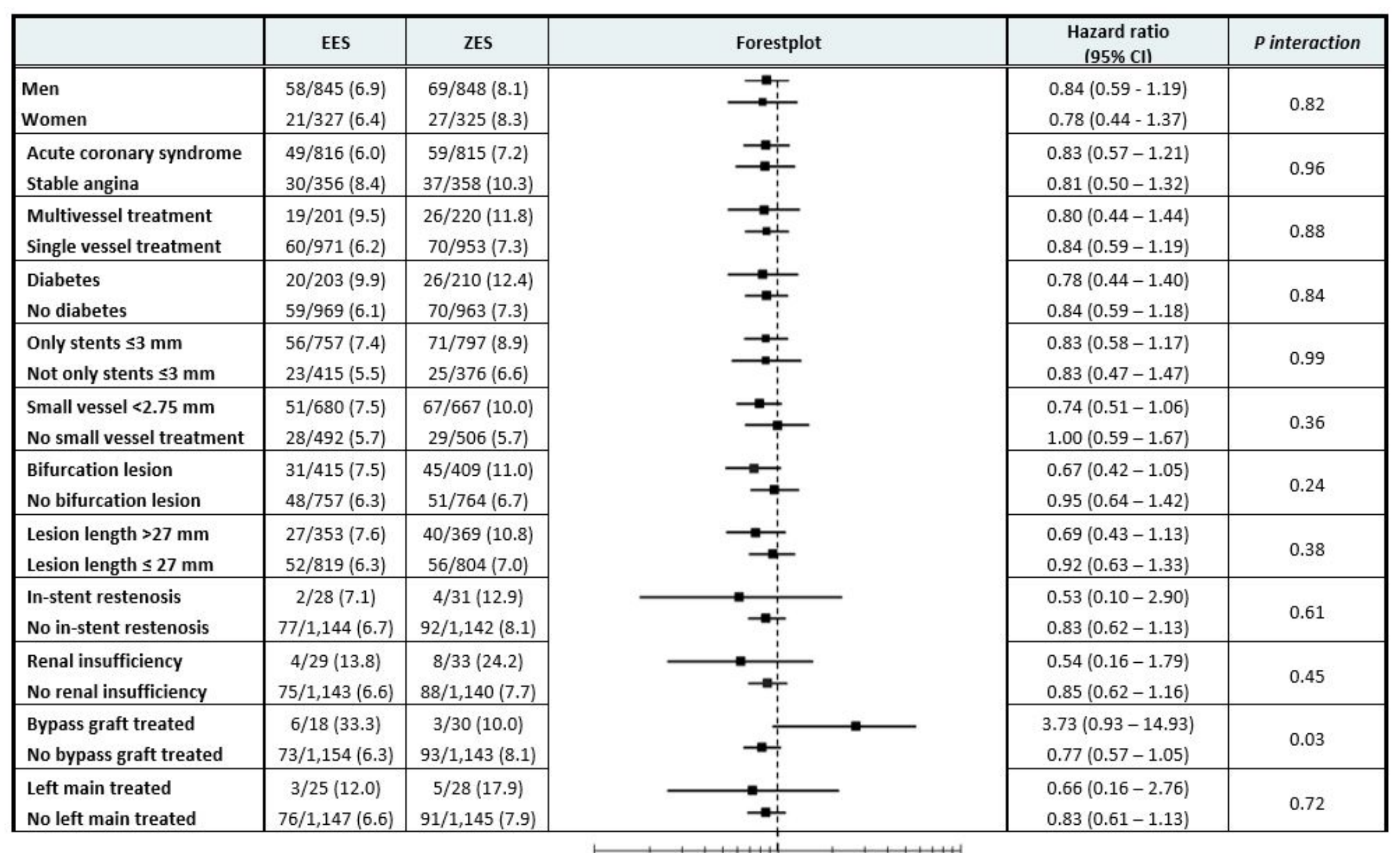

0,1 Favors EES $\quad 1 \quad$ Favors ZES 10

The $p$-value for interaction represents the likelihood of interaction between the variable and the relative treatment effect. 
Supplementary Table 1B. Subgroup analyses for the 2-year rates of target vessel failure: SES versus ZES.

\begin{tabular}{|c|c|c|c|c|c|}
\hline & SES & ZES & Forestplot & $\begin{array}{c}\text { Hazard ratio } \\
(95 \% \mathrm{Cl}) \\
\end{array}$ & P interaction \\
\hline Men & $53 / 854(6.2)$ & $69 / 848(8.1)$ & \multirow{3}{*}{ 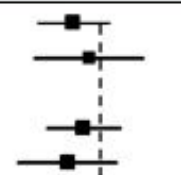 } & $0.75(0.53-1.08)$ & \multirow{2}{*}{0.63} \\
\hline Women & $23 / 315(7.3)$ & $27 / 325(8.3)$ & & $0.89(0.51-1.54)$ & \\
\hline Acute coronary syndrome & $50 / 818(6.1)$ & $59 / 815(7.2)$ & & $0.84(0.58-1.23)$ & \multirow{2}{*}{0.58} \\
\hline Stable angina & $26 / 351(7.4)$ & $37 / 358(10.3)$ & & $0.71(0.43-1.17)$ & \\
\hline Multivessel treatment & $18 / 219(8.2)$ & $26 / 220(11.8)$ & & $0.69(0.38-1.26)$ & \multirow{2}{*}{0.61} \\
\hline Single vessel treatment & $58 / 950(6.1)$ & $70 / 953(7.3)$ & & $0.83(0.58-1.17)$ & \\
\hline Diabetes & $21 / 211(10.0)$ & $26 / 210(12.4)$ & & $0.79(0.44-1.40)$ & \multirow{2}{*}{0.98} \\
\hline No diabetes & $55 / 958(5.7)$ & $70 / 963(7.3)$ & & $0.79(0.55-1.12)$ & \\
\hline Only stents $\leq 3 \mathrm{~mm}$ & $51 / 764(6.7)$ & $71 / 797(8.9)$ & & $0.74(0.52-1.07)$ & \multirow{2}{*}{0.52} \\
\hline Not only stents $\leq 3 \mathrm{~mm}$ & $25 / 405(6.2)$ & $25 / 376(6.6)$ & & $0.92(0.53-1.61)$ & \\
\hline Small vessel $<2.75 \mathrm{~mm}$ & $49 / 731(6.7)$ & $67 / 667(10.0)$ & & $0.66(0.46-0.95)$ & \multirow{2}{*}{0.14} \\
\hline No small vessel treatment & $27 / 438(6.2)$ & $29 / 506(5.7)$ & & $1.07(0.64-1.81)$ & \\
\hline Bifurcation lesion & $32 / 412(7.8)$ & $45 / 409(11.0)$ & & $0.70(0.44-1.10)$ & \multirow{2}{*}{0.48} \\
\hline No bifurcation lesion & $44 / 757(5.8)$ & $51 / 764(6.7)$ & & $0.87(0.58-1.30)$ & \\
\hline Lesion length $>27 \mathrm{~mm}$ & $25 / 351(7.1)$ & $40 / 369(10.8)$ & & $0.65(0.39-1.07)$ & \multirow{2}{*}{0.32} \\
\hline Lesion length $\leq 27 \mathrm{~mm}$ & $51 / 818(6.2)$ & $56 / 804(7.0)$ & & $0.89(0.61-1.30)$ & \\
\hline In-stent restenosis & $1 / 30(3.3)$ & $4 / 31(12.9)$ & & $0.23(0.03-2.10)$ & \multirow{2}{*}{0.28} \\
\hline No in-stent restenosis & $75 / 1,139(6.6)$ & $92 / 1,142(8.1)$ & & $0.81(0.60-1.10)$ & \\
\hline Renal insufficiency & $5 / 46(10.9)$ & $8 / 33(24.2)$ & & $0.42(0.14-1.29)$ & \multirow{2}{*}{0.25} \\
\hline No renal insufficiency & $71 / 1,123(6.3)$ & $88 / 1,140(7.7)$ & & $0.82(0.60-1.11)$ & \\
\hline Bypass graft treated & $4 / 22(18.2)$ & $3 / 30(10.0)$ & & $1.89(0.42-8.44)$ & \multirow{2}{*}{0.24} \\
\hline No bypass graft treated & $72 / 1,147(6.3)$ & $93 / 1,143(8.1)$ & & $0.77(0.56-1.04)$ & \\
\hline Left main treated & $4 / 23(17.4)$ & $5 / 28(17.9)$ & $\rightarrow$ & $0.86(0.23-3.22)$ & \multirow{2}{*}{0.86} \\
\hline No left main treated & $72 / 1,146(6.3)$ & $91 / 1,145(7.9)$ & & $0.79(0.58-1.07)$ & \\
\hline
\end{tabular}

$\begin{array}{lrl}1 & 1 & 1\end{array}$

The $p$-value for interaction represents the likelihood of interaction between the variable and the relative treatment effect. 
Supplementary Table 2. Circumstances and consequences of TLR between 1 and 2 years.

\begin{tabular}{|c|c|c|c|c|c|c|c|}
\hline & \multicolumn{5}{|c|}{ Index PCI } & \multicolumn{2}{|l|}{ Event } \\
\hline $\begin{array}{l}\text { Randomised } \\
\text { stent }\end{array}$ & $\begin{array}{c}\text { Gender } \\
\text { (age) }\end{array}$ & $\begin{array}{c}\text { Clinical } \\
\text { presentation }\end{array}$ & Treated vessel & $\begin{array}{l}\text { Total number } \\
\text { of stents } \\
\text { /total stent } \\
\text { length }\end{array}$ & $\begin{array}{l}\text { Pre/post } \\
\text { dilation } \\
\text { performed }\end{array}$ & $\begin{array}{l}\text { Clinical presentation and } \\
\text { angiographic findings }\end{array}$ & Treatment \\
\hline \multirow{10}{*}{$\begin{array}{l}\text { Everolimus- } \\
\text { eluting stent }\end{array}$} & $\begin{array}{l}\text { Male } \\
(79)\end{array}$ & Stable angina & Graft & $1 / 12$ & Yes/Yes & $\begin{array}{c}\text { Acute } \mathrm{MI}, \mathrm{CK} \max 213 \mathrm{U} / \mathrm{I} \\
\text { Definite ST* }\end{array}$ & $\mathrm{Re}-\mathrm{PCl}$ \\
\hline & $\begin{array}{l}\text { Male } \\
(49) \\
\end{array}$ & Stable angina & LM, LAD, RCX & $5 / 134$ & Yes/Yes & $\begin{array}{c}\text { Stable angina } \\
\text { In-stent restenosis }\end{array}$ & $\mathrm{Re}-\mathrm{PCl}$ \\
\hline & $\begin{array}{l}\text { Male } \\
(57)\end{array}$ & $\begin{array}{l}\text { Unstable } \\
\text { angina }\end{array}$ & LAD & $2 / 28$ & Yes/Yes & $\begin{array}{c}\text { Stable angina } \\
\text { In-stent restenosis }\end{array}$ & $\mathrm{Re}-\mathrm{PCl}$ \\
\hline & $\begin{array}{l}\text { Male } \\
(63)\end{array}$ & NSTEMI & RCA & $2 / 44$ & Yes/Yes & $\begin{array}{c}\text { Stable angina } \\
\text { Diffuse in-stent restenosis }\end{array}$ & $\mathrm{Re}-\mathrm{PCl}$ \\
\hline & $\begin{array}{l}\text { Male } \\
(57)\end{array}$ & Stable angina & $\mathrm{RCX}, \mathrm{RCA}$ & $2 / 24$ & Yes/No & $\begin{array}{l}\text { Stable angina } \\
\text { Mild in-stent hyperplasia and } \\
\text { new stenosis just outside } \\
\text { stents }\end{array}$ & $\mathrm{Re}-\mathrm{PCl}$ \\
\hline & $\begin{array}{l}\text { Male } \\
(69)\end{array}$ & Stable angina & LAD, RCX & $2 / 40$ & Yes/No & $\begin{array}{c}\text { NSTEMI } \\
\text { Stenosis just proximal of } \\
\text { stent RCX }\end{array}$ & $\mathrm{Re}-\mathrm{PCl}$ \\
\hline & $\begin{array}{l}\text { Male } \\
(67)\end{array}$ & NSTEMI & LAD, RCA & $3 / 68$ & Yes/Yes & $\begin{array}{c}\text { Silent ischaemia } \\
\text { Diffuse in-stent restenosis }\end{array}$ & $\mathrm{Re}-\mathrm{PCl}$ \\
\hline & $\begin{array}{c}\text { Female } \\
(62)\end{array}$ & Stable angina & LAD & $2 / 28$ & Yes/Yes & $\begin{array}{l}\text { Unstable angina } \\
\text { In-stent restenosis }\end{array}$ & $\mathrm{Re}-\mathrm{PCl}$ \\
\hline & $\begin{array}{l}\text { Female } \\
(67)\end{array}$ & STEMI & RCA & $2 / 58$ & No/Yes & $\begin{array}{c}\text { Acute } \mathrm{MI}, \mathrm{CK} \max 250 \mathrm{U} / \mathrm{I} \\
\text { Definite ST }{ }^{* *}\end{array}$ & $\mathrm{Re}-\mathrm{PCl}$ \\
\hline & $\begin{array}{l}\text { Male } \\
(67)\end{array}$ & NSTEMI & LAD & $2 / 38$ & Yes/Yes & $\begin{array}{c}\text { Stable angina } \\
\text { In-stent restenosis }\end{array}$ & $\mathrm{Re}-\mathrm{PCl}$ \\
\hline & $\begin{array}{l}\text { Male } \\
(54)\end{array}$ & Stable angina & LAD & $2 / 48$ & Yes/Yes & $\begin{array}{c}\text { Stable angina } \\
\text { In-stent restenosis }\end{array}$ & $\mathrm{Re}-\mathrm{PCl}$ \\
\hline
\end{tabular}




\begin{tabular}{|c|c|c|c|c|c|c|c|}
\hline & $\begin{array}{l}\text { Male } \\
(73)\end{array}$ & Stable angina & $\mathrm{RCX}$ & $2 / 24$ & Yes/Yes & $\begin{array}{c}\text { Stable angina } \\
\text { In-stent restenosis }\end{array}$ & $\mathrm{Re}-\mathrm{PCl}$ \\
\hline & $\begin{array}{l}\text { Male } \\
(86)\end{array}$ & NSTEMI & Graft & $1 / 18$ & No/No & $\begin{array}{c}\text { Acute MI, CK max } 733 \mathrm{U} / \mathrm{I} \\
\text { In-stent restenosis }\end{array}$ & $\mathrm{Re}-\mathrm{PCl}$ \\
\hline & $\begin{array}{l}\text { Male } \\
(56)\end{array}$ & Stable angina & RCA & $3 / 82$ & Yes/Yes & $\begin{array}{l}\text { Unstable angina } \\
\text { In-stent restenosis }\end{array}$ & $\mathrm{Re}-\mathrm{PCl}$ \\
\hline & $\begin{array}{l}\text { Female } \\
(60)\end{array}$ & NSTEMI & LAD & $4 / 100$ & Yes/Yes & $\begin{array}{c}\text { NSTEMI } \\
\text { Ostial in-stent restenosis }\end{array}$ & CABG \\
\hline & $\begin{array}{c}\text { Female } \\
(62)\end{array}$ & $\begin{array}{l}\text { Unstable } \\
\text { angina }\end{array}$ & $\mathrm{LAD}, \mathrm{RCX}$ & $2 / 34$ & Yes/Yes & $\begin{array}{l}\text { Stable angina } \\
\text { Mid and distal in-stent } \\
\text { restenosis }\end{array}$ & $\mathrm{Re}-\mathrm{PCl}$ \\
\hline & $\begin{array}{l}\text { Male } \\
(44)\end{array}$ & NSTEMI & LAD & $2 / 38$ & Yes/Yes & $\begin{array}{c}\text { Acute MI, CK max } 540 \mathrm{U} / \mathrm{I} \\
\text { Definite ST** }\end{array}$ & $\mathrm{Re}-\mathrm{PCl}$ \\
\hline Zotarolimus- & $\begin{array}{c}\text { Female } \\
(70)\end{array}$ & STEMI & $\mathrm{RCX}$ & $2 / 48$ & Yes/Yes & $\begin{array}{c}\text { Stable angina } \\
\text { Stenosis just distal of stent }\end{array}$ & $\mathrm{Re}-\mathrm{PCl}$ \\
\hline $\begin{array}{l}\text { eluting } \\
\text { stent }\end{array}$ & $\begin{array}{l}\text { Male } \\
(64)\end{array}$ & Stable angina & LAD, RCA & $4 / 105$ & Yes/Yes & $\begin{array}{c}\text { Acute MI, CK } \max 185 \mathrm{U} / \mathrm{I} \\
\text { Definite ST*** }\end{array}$ & $\mathrm{Re}-\mathrm{PCl}$ \\
\hline & $\begin{array}{c}\text { Female } \\
(76)\end{array}$ & NSTEMI & RCA & $4 / 65$ & Yes/Yes & $\begin{array}{c}\text { Stable angina } \\
\text { In-stent restenosis }\end{array}$ & Re-PCl \\
\hline & $\begin{array}{c}\text { Female } \\
\text { (69) }\end{array}$ & Stable angina & RCA & $2 / 27$ & Yes/Yes & $\begin{array}{c}\text { Unstable angina } \\
\text { Ostial in-stent restenosis }\end{array}$ & $\mathrm{Re}-\mathrm{PCl}$ \\
\hline & $\begin{array}{l}\text { Male } \\
(53)\end{array}$ & STEMI & RCX & $1 / 15$ & No/Yes & $\begin{array}{c}\text { Stable angina } \\
\text { In-stent restenosis }\end{array}$ & $\mathrm{Re}-\mathrm{PCl}$ \\
\hline & $\begin{array}{l}\text { Male } \\
(62)\end{array}$ & Stable angina & LAD, RCX, RCA & $3 / 48$ & Yes/No & $\begin{array}{c}\text { Stable angina } \\
\text { Chronic in-stent occlusion }\end{array}$ & $\mathrm{Re}-\mathrm{PCl}$ \\
\hline & $\begin{array}{l}\text { Male } \\
\text { (69) }\end{array}$ & $\begin{array}{l}\text { Unstable } \\
\text { angina }\end{array}$ & RCA & $2 / 60$ & Yes/Yes & $\begin{array}{c}\text { Unstable angina } \\
\text { Chronic in-stent occlusion }\end{array}$ & $\mathrm{Re}-\mathrm{PCl}$ \\
\hline & $\begin{array}{l}\text { Male } \\
(56)\end{array}$ & NSTEMI & RCA & $1 / 30$ & Yes/Yes & $\begin{array}{c}\text { Acute MI, CK max } 540 \mathrm{U} / \mathrm{I} \\
\text { Plaque rupture of stenosis } \\
\text { just proximal of stent }\end{array}$ & $\mathrm{Re}-\mathrm{PCl}$ \\
\hline & $\begin{array}{l}\text { Male } \\
(52)\end{array}$ & STEMI & LAD, RCX & $3 / 60$ & Yes/Yes & $\begin{array}{c}\text { Acute } \mathrm{MI}, \mathrm{CK} \max 2460 \mathrm{U} / \mathrm{I} \\
\text { Definite ST** }\end{array}$ & $\mathrm{Re}-\mathrm{PCl}$ \\
\hline
\end{tabular}




\begin{tabular}{|c|c|c|c|c|c|c|c|}
\hline & $\begin{array}{c}\text { Female } \\
(72)\end{array}$ & $\begin{array}{l}\text { Unstable } \\
\text { angina }\end{array}$ & LAD & $1 / 8$ & Yes/No & $\begin{array}{c}\text { Stable angina } \\
\text { In-stent restenosis }\end{array}$ & $\mathrm{Re}-\mathrm{PCl}$ \\
\hline \multirow{7}{*}{$\begin{array}{l}\text { Sirolimus- } \\
\text { eluting stent }\end{array}$} & $\begin{array}{l}\text { Male } \\
(35)\end{array}$ & $\begin{array}{l}\text { Unstable } \\
\text { angina }\end{array}$ & LAD & $1 / 40$ & Yes/Yes & $\begin{array}{c}\text { Acute } \mathrm{MI}, \mathrm{CK} \max 348 \mathrm{U} / \mathrm{I} \\
\text { Definite } \mathrm{ST}^{* *}\end{array}$ & $\mathrm{Re}-\mathrm{PCl}$ \\
\hline & $\begin{array}{l}\text { Male } \\
(70)\end{array}$ & $\begin{array}{l}\text { Unstable } \\
\text { angina }\end{array}$ & RCA & $1 / 40$ & Yes/Yes & $\begin{array}{c}\text { Stable angina } \\
\text { Chronic occlusion just } \\
\text { proximal of stent }\end{array}$ & CABG \\
\hline & $\begin{array}{c}\text { Female } \\
(69) \\
\end{array}$ & Stable angina & $\mathrm{LM}, \mathrm{RCX}$ & $1 / 22$ & Yes/Yes & $\begin{array}{c}\text { Unstable angina } \\
\text { In-stent restenosis }\end{array}$ & $\mathrm{Re}-\mathrm{PCl}$ \\
\hline & $\begin{array}{l}\text { Male } \\
(42)\end{array}$ & STEMI & LAD & $2 / 41$ & Yes/Yes & $\begin{array}{l}\text { Acute MI, CK max } 500 \text { U/l } \\
\text { Stenosis distal stent edge }\end{array}$ & $\mathrm{Re}-\mathrm{PCl}$ \\
\hline & $\begin{array}{l}\text { Male } \\
(54)\end{array}$ & STEMI & LAD & $1 / 30$ & Yes/Yes & $\begin{array}{c}\text { Acute } \mathrm{MI}, \mathrm{CK} \max 449 \mathrm{U} / \mathrm{I} \\
\text { In-stent restenosis }\end{array}$ & $\mathrm{Re}-\mathrm{PCl}$ \\
\hline & $\begin{array}{l}\text { Male } \\
(65)\end{array}$ & $\begin{array}{l}\text { Unstable } \\
\text { angina }\end{array}$ & LAD & $1 / 30$ & Yes/No & $\begin{array}{c}\text { NSTEMI } \\
\text { In-stent restenosis }\end{array}$ & $\mathrm{Re}-\mathrm{PCl}$ \\
\hline & $\begin{array}{c}\text { Female } \\
(62)\end{array}$ & Stable angina & LAD, RCX & $2 / 43$ & Yes/Yes & $\begin{array}{l}\text { Unstable angina } \\
\text { Stenosis just distal of stent }\end{array}$ & $\mathrm{Re}-\mathrm{PCl}$ \\
\hline
\end{tabular}

All index $\mathrm{PCl}$ were performed for de novo lesions except for 2 patients in the zotarolimus-eluting stent group.

* on clopidogrel-based dual antiplatelet therapy.

** on aspirin single antiplatelet therapy.

*** on oral anticoagulation therapy

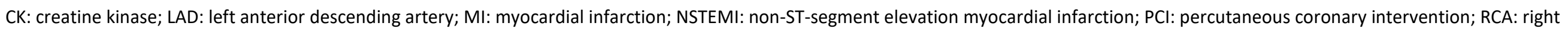
coronary artery; RCX: ramus circumflex artery; ST: stent thrombosis; STEMI: ST-segment elevation myocardial infarction; TLR: target lesion revascularisation 